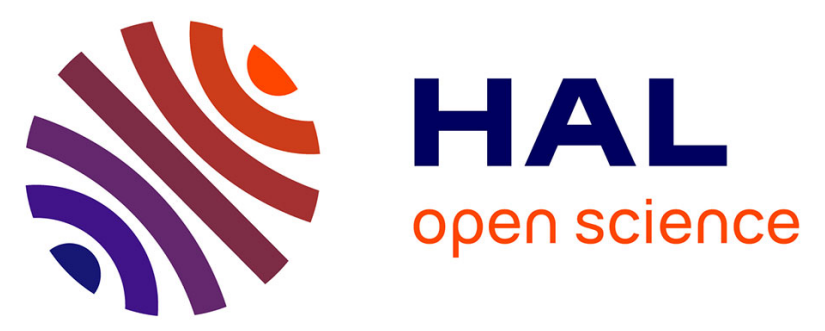

\title{
Impacts of International Sports Events on the Stock Market: Evidence from the Announcement of the 18th Asian Games and 30th Southeast Asian Games
}

Dwipraptono Agus Harjito, Md. Mahmudul Alam, Rani Ayu Kusuma Dewi

\section{- To cite this version:}

Dwipraptono Agus Harjito, Md. Mahmudul Alam, Rani Ayu Kusuma Dewi. Impacts of International Sports Events on the Stock Market: Evidence from the Announcement of the 18th Asian Games and 30th Southeast Asian Games. International Journal of Sport Finance, 2021, 16 (3), 10.32731/ijsf/163.082021.03 . hal-03538176

\author{
HAL Id: hal-03538176 \\ https://hal.science/hal-03538176
}

Submitted on 20 Jan 2022

HAL is a multi-disciplinary open access archive for the deposit and dissemination of scientific research documents, whether they are published or not. The documents may come from teaching and research institutions in France or abroad, or from public or private research centers.
L'archive ouverte pluridisciplinaire $\mathbf{H A L}$, est destinée au dépôt et à la diffusion de documents scientifiques de niveau recherche, publiés ou non, émanant des établissements d'enseignement et de recherche français ou étrangers, des laboratoires publics ou privés. 
Impacts of International Sports Events on the Stock Market: Evidence from the Announcement of the $18^{\text {th }}$ Asian Games and $30^{\text {th }}$ Southeast Asian Games

\author{
Dwipraptono Agus Harjito * \\ Management Department \\ Universitas Islam Indonesia \\ Email: agus_h@uii.ac.id
}

\author{
Md. Mahmudul Alam * \\ Economic and Financial Policy Institute \\ School of Economics, Finance \& Banking \\ Universiti Utara Malaysia \\ 06010 UUM Sintok, Kedah, Malaysia \\ E-mail: rony000@gmail.com \\ ORCID: http://orcid.org/0000-0002-7360-1259
}

\author{
Rani Ayu Kusuma Dewi \\ Management Department \\ Universitas Islam Indonesia \\ Email: raniayu@yahoo.com \\ * Corresponding author
}

\title{
Citation Reference:
}

Harjito, D.A., Alam, M.M., \& Dewi, R.A.K (2021). Impacts of International Sports Events on the Stock Market: Evidence from the Announcement of the 18th Asian Games and 30th Southeast Asian Games. International Journal of Sport Finance, 16(3), 139-147. (online) http://doi.org/10.32731/IJSF/163.082021.03

This is a pre-publication copy.

The published article is copyrighted by the publisher of the journal. 


\title{
Impacts of International Sports Events on the Stock Market: Evidence from the Announcement of the $18^{\text {th }}$ Asian Games and $30^{\text {th }}$ Southeast Asian Games
}

\begin{abstract}
This research assesses the influence of hosting major international sporting competitions on the host countries' stock market performance before and after the announcement of such events. Specifically, this study explores whether stock markets of hosting countries experience cumulative average abnormal return (CAAR) during the aforementioned period. For the purposes of investigation, the study considers announcements of the 18th Asian Games and 30th SEA Games hosted by Indonesia and the Philippines, respectively. The LQ45 index of the Indonesia Stock Exchange (IDX) and PSEi index of the Philippines Stock Exchange (PSE) were chosen to test the significance of these events. It is found that only PSE has experienced a significantly positive CAAR for the event. Findings of this study can make a significant contribution to helping national governments and investors understand the significance of sports to the economies of developing countries and how major sports events can improve stock market efficiency.
\end{abstract}

Keywords: Event study; International sporting event; Asian games; Southeast Asian Games; Stock market

\section{JEL Code: 614, G15}

\section{Introduction}

International sports events or mega-sporting events are the sports competitions where the participants join from many countries. These sporting competitions today are crucial events in which not only professional athletes representing their country compete for excellence, but also offer a universally legitimate means for host nations to portray and cultivate their national identities and cultures on a global scale (Dollesa \& Soderman, 2008). Major sporting events (such as, the World Football Cup, the European Football Cup, Summer and Winter Olympic Games, and World and Specialized Exhibitions) may have an economic, social and cultural impact on the host country and/or region, as well as contribute to innovations, science and technology (Chanaron, 2014). In recent decades, many countries have left no stone unturned to win a bid for hosting international sports events to obtain the best possible economic advantages of hosting such events. For example, the World Cup has long been a high-profile event, with the 2006 World Cup in Germany attracting more than 20 billion television viewers (Fédération Internationale de Football Association, 2010). World Cup fixtures have been considered as worthy investments because it creates opportunities for host countries to receive huge earnings from sponsorship, advertising, sales of products and boosting tourism (Anton, Alonso, and Rodriguez, 2011). The results show that tourism is enhanced by major sporting events, but the benefits depend on the type of event, the country in which it is played and whether it takes place in high or low seasons (Fourie \& Santana-Gallego, 2011). Nauright (2004) notes that, in the form of new infrastructure and foreign cash contributions, the host country of an international sporting event earns economic benefits. Besides, these events bring social benefits to the hosting communities (Tien, Lo, \& Lin, 2011) because international tourists can wield a great influence on tournaments that are broadcast globally (Hill, 2000).

Major sports events, by signal power and educational opportunities, promote the growth of the green economy (Preuss, 2013). In terms of the idea of a global village, the sports industry is 
also booming. In the 20th century, the sports sector was a $\$ 213$ billion organisation and listed as the sixth largest industry in the United States. In the new millennium, the global sports business has already surpassed US\$ 500 billion (Huang \& Chang, 2011). Researchers have analyzed the effect of UEFA Euro 2012 on the Polish economy and found that accelerated investment in transport infrastructure, which encouraged the growth of total productivity factor and the inflow of foreign direct investment, was the key source of economic benefits. Under the basic scenario, aggregate real GDP growth is equal to $2.1 \%$ of 2009 GDP (Borowski et al., 2013). Due to the continuous growth of the sports industry in recent decades, international sports events have started to impact significantly on the world's financial markets. Therefore, the announcement of major sports events does influence host countries' stock markets, as noted by Martins and Serra $(2009,2007)$ who claimed that market responses are positive for winners and negative for losers when the announcement news are absolute surprises.

In contrast, Coates and Humphreys (2008) present an economic intuition-based case against sports subsidies and the economic effects of professional sports. According to them, most of the economists believe that sports subsidies are unnecessary. The authors firmly condemn sports subsidies due to a lack of financial benefits They also claim that the rapidly expanding peer-reviewed economics literature on the economic effects of arenas, stadiums, sport mega events and sports franchises has clearly demonstrated little evidence of increased employment, salaries, or levy revenues for a population associated with any of these activities. They conclude that if major league sports franchises and services have no substantial beneficial economic effect in the local economy, subsidies for their construction and maintenance would be much harder to ascertain.

Moreover, many major international sporting competitions, such as the Olympic Games and the World Cup, have been held mainly in developed countries over the past few decades and therefore, the economic studies on major international sports events are mostly based on developed countries. At the same time, there is very little available evidence on the emerging markets through Charles and Darne (2016) show investors in developing countries are more sensitive than developed countries in terms of sports events announcements. Therefore, more studies should be undertaken in emerging countries to explore the connection between announcement of the major sports events and performance of stock indices in the host countries. To fulfil this gap in the literature, this research explores the impact of announcement of hosting both the $18^{\text {th }}$ Asian Games on the Indonesian Stock Exchange (IDX) and $30^{\text {th }}$ Southeast Asian Games on the Philippines Stock Exchange (PSE).

The research has important implications for policymakers, stock market investors, sports and other related industries in emerging countries. Stakeholders will be able to reflect on how to organize major sports events and the impacts on emerging countries' stock markets. Through Event Study research, this research makes it possible for governments in emerging countries to see the economic benefits of hosting international sports events and help policymakers to consider the possibility of bidding for future events. This study will assist stock market authorities and investors to better comprehend the impact of sports events on the stock market, enrich the investment strategies and improve the market's efficiency.

\section{Literature Review and Theoretical Background}

Overall, it is considered that there is a positive relationship between the stock market and economic development. Stock markets facilitate organizations to raise capital for their growth and development. It also provides the trading platform with which investors buy and sell their 
stocks. Different stock market indices are used to observe the market's performance generally. These indices are numerical representations of how well the prices of stocks has moved compared to a base index that is past the start date.

The theory of Efficient Market Hypothesis (EMH) contends that stock prices fully reflect all the relevant information that is available about a stock in the market (Sathyanarayana \& Gargesha, 2017). There are three forms of market efficiency. Firstly, the Weak form Efficient Market Hypothesis states that all available knowledge on past share prices is completely incorporated into the present stock prices. Secondly, the Semi-Strong Form of Efficient Market Hypothesis is one in which all publicly accessible knowledge, along with previous share prices, is reflected in the current share prices. Thirdly, the Strong Efficient Market Hypothesis says all the available knowledge (both public and private) is expressed in stock prices (Alam \& Akbar, 2015). A securities market is causally effective with regard to an information system if and only if security prices behave as if the information system is known to all. When this condition holds, the knowledge system is said to be completely expressed by prices. If one could be sure that the price will increase, it would have risen already. Arguments such as this are used to deduce that competitive markets must show price changes that conduct a random walk without predictable bias. The theory includes identifying a successful market as one in which an abnormal benefit is not generated by trading on available knowledge. Researchers questioned the theory of successful markets and argued that news is volatile by definition, and that price shifts must also be volatile and spontaneous (Sanchez-Granero, 2020; Ardalan, 2018; Khan et al., 2017).

Therefore, when prices adapt rapidly and on average without prejudice to new information, what drives or serves as the engine behind price changes is the introduction of new information and a market is said to be "efficient". Economic, non-economic and political events affect the output of capital markets (Nazir et al., 2014). The financial markets as a whole are influenced by macroeconomic factors such as interest rates, inflation, monetary and fiscal policy (Nazir et al., 2014). In the meantime, microeconomic conditions impact the business success of individual companies (Nazir et al., 2014). Non-economic incidents such as earthquakes, flooding, aircraft accidents and natural disasters can also greatly affect the stock market (Bourdeau-Briena \& Kryzanowski, 2020). The returns of stock indices are also influenced by many other variables, and it is not appropriate to assume that stock markets react to any particular event in the same way. Shiller (2003) clarified that such events appear to overreact or underreact to the stock market, which contradicts the EMT. Therefore, this study shows the impacts of hosting international sports event on two Asian emerging markets, which will reflect the level of market efficiency of these countries through adjustment of the good information in the price.

There has been a dearth of studies that explore stock market sentiments of those countries which announce the hosting of major international sports. The relationship between the success of England's football team and changes in the FTSE 100 index from January 1984 to July 2002 was investigated by Ashton et al. (2003). This experimental study reveals there is a correlation between English football teams' performance and changes in price on the UK's stock market. Berman et al. (2000) conducted a study that assessed the effect on the Australian Stock Exchange (ASX) when Sydney was announced as the host city for the 2000 Olympic Games. The research conducted by Berman et al. (2000) used nine-year stock data for the All Ordinaries Index and 23 accumulation indices on the ASX. Results show that the announcement did not affect the ASX significantly. Consequently, the study used a market model for those 23 ASX industry accumulation indices and shows that the announcement of the Games elevated the 
stock prices of some industries like construction, building materials and engineering. An investigation was further undertaken on a comparative performance analysis between stocks based on hosting state (New South Wales) and non-hosting state. Subsequent results revealed that stocks with head offices in NSW gained significantly during the period.

Similarly, Ramdas et al. (2015) checked the reaction of stock markets to the FIFA World Cup hosting announcement from 1994 to 2010 in five host countries, discovering that the stock market in South Africa experienced a positive trend on the date that the tournament was announced. Veraros, Kasimati and Dawson (2004) analyzed the effect of the host city's 2004 Olympic Games announcement on the Greek and Italian stock exchanges and found a substantial positive impact on the Athens Stock Exchange. Yet for the losing country (Milan Stock Exchange), no (negative) effect is observed. Floros (2010) strongly recommends that state sponsors invest more frequently in major sporting events, such as the Olympics, to give share prices a positive value. The announcement of the host country of the Olympic Games had a major positive impact on the abnormal returns of S\&P Global 1200 Index shares around the date of the occurrence, Mirman and Sharma (2010) also found. The results documented by Gopane and Mmotla (2019), Charles and Darne (2016), Ramdas et al. (2015) and Abuzayed (2013) prove that the stock market reaction of Germany, South Africa and Qatar is positive when the right to host the World Cup was claimed.

On the other hand, Martins and Serra (2009) argue that the announcement of a major international sporting event has a negative impact on the stock market of the host country. Martins and Serra (2009) suggest that stock markets do not necessarily provide a positive response to good news, while the hosting of an international sporting event is seen as a positive news signal. Japan's stock market revealed a decline a day after the announcement of Japan's right to host the football World Cup in 2002 (Manzenreiter, 2008). Liu (2011) found that when Beijing failed to bid for the Olympic Games in 2000, there was no obvious change of cumulative abnormal returns in the major stock market indices. However, when Beijing failed to bid for the Olympic Games in 2008, these indices demonstrated a clear negative impact. In addition, the outcome for B shares is positive to the failure of Beijing's Olympic Games bid, but negative to the success of Beijing's bid. Ramdas et al. (2015) found the negative reaction of French and South Korean stock markets when the two countries obtained the right to host the World Cup. Charles and Darne (2016), Gopane and Mmotla (2019) also demonstrated that stock market reaction of the countries that lost the hosting rights (Morocco and Egypt) was also negative. Investors in these countries claim that hosting the World Cup will have a positive economic outcome for the host country, according to Charles and Darne (2016). However, losing the right to host means losing an opportunity to stimulate economic development. Martins and Serra (2009) clarify that host nations winning the bid to host an international sporting event are showing a positive reaction to stock market returns, whereas those countries losing the bid are showing a negative reaction to stock market prices.

However, studies such as Engelhardt et al. (2018) contend that the influence of announcements from host countries on stock market returns does not affect the stock markets of the bidding countries. There was also no conclusive association between staging international sporting events and stock market reactions in the studies by Kaplanski and Levy (2010) and Martins and Serra (2009). Andreas et al. (2020) assess whether when Indonesia was declared the host of the 2018 XVIII Asian Games, the Indonesian stock market demonstrates direct reaction. The findings disclose the rare returns two days before and two days after the announcement. However, usually, before and after the declaration, there are no noticeable abnormal returns. Andreas et al. (2020) explain that participants in the capital market do not consider the 
occurrence to be a significant problem that influences the capital market investment decisions. As there is no collusive evidence available on the impact of sport event announcement in the economy of host country, there is scope for further study on this issue.

\section{Methodology}

In this study, the observed indices data were collected from respected stock exchange websites - the LQ45 index data from Indonesian Stock Exchange (IDX) and the PSEi index data from Philippines Stock Exchange (PSE), which are openly available. To analyse the impact of hosting major international sporting events on the stock market performance of the host countries before and after the announcement of such events, this research paper uses Event Study analysis. In these kinds of studies, financial markets' data are used to measure financial returns linked to new market information. Event studies are applied to investigate various events specific to corporations and economic systems, where the abnormal return of an event is calculated. It is the difference that the stock or index receives over a selected event window between actual return and usual return. The event window is the timeframe that the investigator wants to examine, and the date of the event is included (Pandey \& Kumari, 2021; Alam et al., 2021; Maneenop \& Kotcharin, 2020; Buigut \& Kapar, 2019; Eastman et al., 2010).

The difference between the real return and the predicted return estimated every day is calculated as an abnormal return. The real return of individual stocks is determined using the following formula:

$$
R_{t}=\frac{\operatorname{Ln}\left(P_{t}\right)}{\operatorname{Ln}\left(P_{t-1}\right)}
$$

Expected returns are determined using the market-adjusted model. This model shows that the market return is the best estimator for calculating returns. The following equation estimates abnormal returns using:

$$
A R_{t}=R_{t}-E(R)_{t}
$$

AARs refer to the average abnormal return, and over a given time interval, CAARs reflect the average cumulative impact of the event for all businesses. The t-test assumes that the abnormal returns of individuals are cross-sectionally independent and equally distributed. By dividing CAARs by standard deviation, $t$-statistics for CAARs are also estimated:

$$
t_{C A A R}=\frac{C A A R}{\sqrt{T * S(A A R)}}
$$

where,

$$
S(A A R)=\sqrt{\sum_{t=1}^{T_{0}} \frac{\sum A A R_{t}^{2}}{T_{0}-1}}
$$

$\mathrm{T}_{0=}$ number of days in the estimated window

If statistical tests show that t-statistics are higher or equal to a crucial price, then this means that CAARs are statistically significant.

For a 10-day window, this study calculates the return based on Cumulative Average Abnormal Return (CAAR), meaning 10 days before and 10 days after the occurrence. It then measures 
the meaning of the return using the t-test and - using the Kolmogorov-Smirnov and ShapiroWilk measures - checks the normality of the return results.

This study examines the impact of the $18^{\text {th }}$ Asian Games hosted by Indonesia by using the data of LQ45 index, which consists of all 569 listed stocks on the Indonesian Stock Exchange (IDX). The event announcement date was 19 September 2014 and the CAAR is calculated based on 10 days before and 10 days after the announcement date. Moreover, this study examines the impact of the $30^{\text {th }}$ Southeast Asian Games hosted by the Philippines, using the data of PSEi index. It consists of all 324 listed stocks on the Philippines Stock Exchange (PSE). The event announcement date was 16 August, 2017 and the CAAR is calculated based on 10 days before and 10 days following the announcement date.

\section{Result and Findings}

\subsection{Descriptive Statistics}

The daily return for LQ45 and PSEi was determined in the analysis within 10 days prior to the announcement and 10 days following the announcement (Table 1). The average return indicates that both before and after the announcement, the announcement of Indonesia's hosting of the 18th Asian Games 2014 had a negative impact on its stock market. On the other hand, the announcement of the Philippines' hosting of the 30th SEA Games, 2017 had a positive effect on that country's stock market both before and after the announcement.

Table 1: The CAAR window returns of the events

\begin{tabular}{lccccc}
\hline \multicolumn{1}{c}{ Events } & $\mathrm{N}$ & $\begin{array}{c}\text { Minimum } \\
\text { Return }\end{array}$ & $\begin{array}{c}\text { Maximum } \\
\text { Return }\end{array}$ & $\begin{array}{c}\text { Average } \\
\text { Return }\end{array}$ & $\begin{array}{c}\text { Std. } \\
\text { Deviation }\end{array}$ \\
\hline CAAR before announcement of ASIAN Games & 10 & -.0139 & -.0006 & -.0073 & .0042 \\
CAAR on day of announcement of ASIAN Games & 1 & -- & -- & -.0059 & -- \\
CAAR after announcement of ASIAN Games & 10 & -.0287 & -.0064 & -.0161 & .0075 \\
\hline CAAR before announcement of SEA Games & 10 & -.0007 & .0209 & .0090 & .0066 \\
CAAR on day of announcement of SEA Games & 1 & -- & -- & .0159 & -- \\
CAAR after announcement of SEA Games & 10 & .0130 & .0276 & .0200 & .0057 \\
\hline
\end{tabular}

\subsection{Hypothesis Testing}

Hypothesis testing served to determine whether cumulative average abnormal return (CAAR) makes any statistically significant difference before and after the announcement of both events (Table 2). The announcement of 27th Asian Games shows an overall negative affect on the Indonesian stock market with a mean of -0.0088 for CAAR, but it is not statistically significant.

Nonetheless the announcement of the 30th SEA Games shows a statistically significant positive effect on the Philippines stock market at the $1 \%$ significance level with a mean of 0.0110 for CAAR. For this country, it is perceived that investors had responded quickly to this announcement news which led the market become significantly abnormal during the period.

Table 2: The cumulative average abnormal return (CAAR) of the events 
CAAR 10 days before and after announcement of $-.0088$ .0094 .00298 .016 ASIAN Games

CAAR 10 days before and after announcement of SEA $.0110 *$ .0080 .00253 Games

* indicates significance at the $1 \%$ level

\subsection{Diagnostic Test}

This study checks the normality of data using Kolmogorov-Smirnov and Shapiro-Wilk tests to decide the best significance test form. The data is usually distributed if, for these measures, the significance value is $>0.05$. The t-test will be performed to test the importance of CAAR if the data is usually distributed. However, if the data is not usually distributed, the Wilcoxon-signed rank test is accompanied by the significant CAAR test.

Table 3: Data normality tests for CAAR events

\begin{tabular}{lccccccc}
\hline & \multicolumn{3}{c}{ Kolmogorov-Smirnov } & \multicolumn{3}{c}{ Shapiro-Wilk } \\
\cline { 2 - 7 } & Statistic & df & Sig. & Statistic & df & Sig. \\
\hline CAAR before announcement of Asian Games & .185 & 10 & .200 & .962 & 10 & .806 \\
CAAR after announcement of Asian Games & .148 & 10 & .200 & .951 & 10 & .686 \\
\hline CAAR before announcement of SEA Games & .110 & 10 & .200 & .980 & 10 & .964 \\
CAAR after announcement of SEA Games & .198 & 10 & .200 & .885 & 10 & .150 \\
\hline
\end{tabular}

In both cases the results of the Kolmogorov-Smirnov and Shapiro-Wilk tests show the return data before and after the events are normally distributed (Table 3). Consequently, this study follows t-test to analyze the significance of CAAR.

\section{Discussion}

The findings show that the announcement of 27th Asian Games does not make a statistically significant impact on the Indonesian stock market. However, the announcement of the 30th SEA Games had statistically significant positive effects on the Philippines stock market.

Similar to the findings of this study, previous research found mixed results (see Andreas et al., 2020; Gopane \& Mmotla, 2019; Charles \& Darne, 2016; Ramdas et al., 2015; Abuzayed, 2013; Mirman \& Sharma, 2010; Kaplanski \& Levy, 2010; Nishio, Lim \& Downward, 2009; Martins \& Serra, 2009; Benkraiem et al., 2009; Veraros et al., 2004; Berman, Brooks \& Davidson, 2000). All of these claim that the host countries' stock markets react to major sporting events in different ways. For example, in the event analysis on the effect of hosting the FIFA World Cup on the stock markets of the host country, Ramdas et al. (2015) discovered that the stock markets of South Korea and Germany witnessed an increase in CAARs just one day after the announcement date, while the remaining countries experienced a decline in CAARs. Ramdas et al. (2015) further found that 10 days after the date of announcement, stock markets of South 
Africa and Germany showed increased returns, but the French and South Korean stock markets closed with negative CAARs. Meanwhile the USA and Japan showed no significant changes in CAARs.

According to the EMH perspective, a market is said to be "effective" if prices respond to new knowledge rapidly and on average without bias. The Efficient Market Hypothesis suggests that all the relevant knowledge available about a market stock is completely expressed in stock prices and no one can get abnormal profit from market (Alam et al., 2017; Sathyanarayana \& Gargesha, 2017). From the findings of the study, it can be said that Indonesian stock market adjusted the news effectively and there was no abnormality in the market but Philippines stock market did not properly adjusted the news. Therefore, the Indonesian market is efficient in the weak-form but the Philippines market is not efficient in weak-form. Referring to the Indonesian market, Almudhaf (2018), Andrianto and Mirza (2016), and Yang and Pangastuti (2016) observed a similar finding. In the case of the Philippines stock market, Shaik and Maheswaran (2017) found a similar outcome.

Calculating the abnormal returns is critical to the Event Study analysis method. There are multiple events which can happen at the same time. Therefore, the reflection of major sports event in the stock market is not always significant or even not required to be unidirectional. Moreover, it depends on the sentiment, support and what the general public finds to be acceptable. Therefore, investors and government authorities should be careful about the willingness of the general public to accept the event if the market is to predict it accurately.

\section{Conclusion}

Many external factors are responsible for stock returns being affected abnormally, such as GDP, inflation, interest rates, political turmoil, labor unrest, natural calamities, etc. However, the study shows that major sports events that have been hosted with international coverage might also be one of the many market factors affecting how well the stock market performs. This study was conducted based on two emerging markets and interestingly found that the Philippines stock market is statistically significantly responsive to the sports event, but the Indonesian stock market is not responsive.

These findings also indicate that some emerging markets are more efficient than others and responsive to external news and events. The findings also show that sports event announcements are important for investors, stock market authorities, policymakers and monitoring agencies to improve the market's efficiency. It also offers another indication concerning the importance of the sports industry for a country, especially if it is an emerging market economy. Moreover, these findings have paved the way for further research on such event studies. For example, the constituents of any stock index comprise stocks of different industries like manufacturing, finance and banking, logistics \& transportation, journalism and mass-media, construction, etc. Therefore, future research could analyze stock returns according to the nature of the industry or sector. It would be worth researching how the stocks of tourism, construction and services industries in the host countries perform on the stock market following the announcement of international sports events. 


\section{References}

Abuzayed, B. (2013). Sport and emerging capital markets: market reaction to the 2022 World Cup announcement. International Journal of Islamic and Middle Eastern Finance and Management, 6(2), 122-141.

Alam, M.M., \& Akbar, C.S. (2015). Rationality of the Capital Market: Capitalistic System vs. Islamic System. International Journal of Behavioural Accounting and Finance, 5(3-4), 279-297.

Alam, M.M., Akbar, C.S., Shahriar, S.M., \& Elahi, M.M. (2017). The Islamic Shariah Principles for Investment in Stock Market. Qualitative Research in Financial Markets, 9(2), 132-146.

Alam, M.M., Wei, H., \& Wahid, A.N.M. (2021). COVID-19 Outbreak and Sectoral Performance of the Australian Stock Market: An Event Study Analysis. Australian Economic Papers, 60, e12215. DOI: 10.1111/1467-8454.12215.

Almudhaf, F. (2018). Predictability, Price Bubbles, and Efficiency in the Indonesian StockMarket. Bulletin of Indonesian Economic Studies, 54(1), 113-124.

Andreas, Gumanti, T.A., Nurjannah, U. and Awwaliyah, I.N. (2020). The effect of announcement as the host of xviii Asian games on the Indonesian stock market. Investment Management and Financial Innovations, 17(1), 109-118.

Andrianto, Y. \& Mirza, A.R. (2016). A Testing of Efficient Markets Hypothesis in Indonesia Stock Market. Procedia - Social and Behavioral Sciences, 219, 99-103.

Anton, A., Alonso, J. \& Rodriguez, G. (2011). Mega Events Impact on Economic Growth: Analysis of the South African World Cup. African Journal of Business Management, 5(16), 6940-6948.

Ardalan, K (2018). Neurofinance versus the efficient markets hypothesis. Global Finance Journal, 35, 170-176.

Ashton, J., B. Gerrard \& R. Hudson (2003). Economic impact of national sporting success: evidence from the London stock exchange. Applied Economics Letters, 10, 783-785.

Assessing the impact of the 2012 European Football Championships on the Polish economy. International Journal of Sport Management and Marketing, 13(1-2), 74-103.

Benkraiem, R., Louhichi, W. \& Marques, P. (2009). Market reaction to sporting results: The case of European listed football clubs. Management Decision, 47(1), 100-109.

Berman, G., R. Brooks, and Davidson, S. (2000). The Sydney Olympic Games Announcement and Australia Stock Market Reaction. Applied Economic Letters 7(12), 781-784.

Borowski, J., Boratyński, J., Czerniak, A., Dykas, P. (2013). Assessing the impact of the 2012 European Football Championships on the Polish economy. Int. J. of Sport Management and Marketing, 13(1/2), 74-103.

Bourdeau-Briena, M. \& Kryzanowski, L. (2020). Natural disasters and risk aversion, Journal of Economic Behavior \& Organization, 177, 818-835.

Buigut, S., \& Kapar, B. (2019). Effect of Qatar diplomatic and economic isolation on GCC stock markets: An event study approach. Finance Research Letters, 101352. DOI: https://doi.org/10.1016/j.frl.2019.101352

Chanaron, J.J. (2014). Technology and economic impacts of mega-sports events: A key issue? Exploratory insights from literature. Megatrend Revija, 11(4), 9-30.

Charles, A., \& Darne, O. (2016). Stock market reactions to FIFA World Cup announcements: An event study. Economics Bulletin, 36(4), 2028-2036.

Coates, D., \& Humphreys, B. R. (2008). Do economists reach a conclusion on subsidies for sports franchises, stadiums, and mega-events. Econ Journal Watch, 5(3), 294-315. 
Dollesa, H., \& Soderman, S. (2008). Mega-Sporting Events in Asia - Impacts on Society, Business and Management: An Introduction. Asian Business \& Management, 7, 147162.

Eastman, J.K., Iyer, R. \& Wiggenhorn, J.M. (2010). The Short-Term Impact Of Super Bowl Advertising On Stock Prices: An Exploratory Event Study. Journal of Applied Business Research, 26(6), 69-84.

Engelhardt, B., Matheson, V.A., Yen, A. \& Chisolm, M. (2018). The Economic Impact of Olympic Games: Effects of Host Country Announcements on Stock Market Returns. International Journal of Sport Finance, 13(3), 243-260.

Fédération Internationale de Football Association. (Ed.) (2010). FACT sheet: FIFA world cup - TV viewing figures. Retrieved November 8, 2020, from http://www.centrostudisport.it/PDF/FIFA/140.pdf

Floros, C. (2010). The impact of the Athens Olympic Games on the Athens Stock Exchange. Journal of Economic Studies, 37(6), 647-657.

Fourie, J., \& Santana-Gallego, M. (2011). The impact of mega-sport events on tourist arrivals. Tourism Management, 32(6), 1364-1370.

Gopane, T.J. \& Mmotla, R.M. (2019). Stock Market Reaction to Mega-Sport Events: Evidence from South Africa and Morocco. International Journal of Sport Finance, 14,193-210.

Griffin, J.M., Kelly, P.J. and Nardari, F. (2010). Do Market Efficiency Measures Yield Correct Inferences? A Comparison of Developed and Emerging Markets. The Review of Financial Studies, 23(8), 3225-3277.

Hill, H.H. (2000). Mega-Events, Urban Boosterism and Growth Strategies: An Analysis of the Objectives and Legitimations of the Cape Town 2004 Olympic bid. International Journal of Urban and Regional Research, 24(2), 439-458.

Huang, S.C., \& Chang, H.C. (2011). The Development of Asian Sport Industry. Asian Journal of Physical Education \& Recreation, 17(1), 25-30.

Kaplanski, G. \& Levy, H. (2010). Exploitable predictable irrationality: the FIFA World Cup effect on the U.S. stock market. Journal of Financial and Quantitative Analysis, 45(2), 535-553.

Katusiime, L., Shamsuddin, A and Agbola, F. W. (2015). Foreign exchange market efficiency and profitability of trading rules: Evidence from a developing country. International Review of Economics \& Finance, 35, 315-332.

Khan, H.H., Kutan, A.M., Naz, I., \& Qureshi, F. (2017). Efficiency, growth and market power in the banking industry: New approach to efficient structure hypothesis. North American Journal of Economics and Finance, 42, 531-545.

Liu, Y. (2011). The 2000 and 2008 Olympic Host Announcements and Chinese Stock Market Responses. International Journal of Applied Economics, 8(2), 43-62.

Maneenop, S. \& Kotcharin, S. (2020). The impacts of COVID-19 on the global airline industry: An event study approach. Journal of Air Transport Management, 89, 101920.

Manzenreiter, W. (2008). The 'Benefits' of Hosting: Japanese Experiences from the 2002 Football World Cup. Asian Business \& Management, 7, 201-224.

Martins, A., \& Serra, A. (2007). Market Impact of International Sporting and Cultural Events. Working Papers 0720, International Association of Sports Economists; North American Association of Sports Economists. SSRN Electronic Journal.

Martins, A., \& Serra, A. (2009). Market impact of international sporting and cultural events. Journal of Economics and Finance, 35(4), 382-416.

Mirman, M., \& Sharma, R. (2010). Stock market reaction to Olympic Games announcement. Applied Economic Letters, 17(5), 463-466.

Nauright, J. (2004). Global games: culture, political economy and sport in the globalized world of the 21st century. Third World Quarterly, 25(7), 1325-1336. 
Nazir, S. M., Younus, H., Kaleem, A., \& Anwar, Z. (2014). Impact of Political Events on Stock Market Returns: Empirical Evidence from Pakistan. Journal of Economic and Administrative Science, 30(1), 60-78.

Nishio, T., Lim, C. \& Downward, P. (2009). Analysing the economic impact of the Olympics using stock market indices of host countries. $18^{\text {th }}$ World IMACS / MODSIM Congress held in Cairns, Australia.

Pandey, D.K. \& Kumari, V. (2021) Event study on the reaction of the developed and emerging stock markets to the 2019-nCoV outbreak. International Review of Economics and Finance, 71, 467-483.

Pradhan, R., Arvin, B., Norman, R., \& Hall, J. (2014). The Dynamics of Banking Sector and Stock Market Maturity and the Performance of Asian Economies. Journal of Economic and Administrative Sciences, 30(1), 16-44.

Preuss, H. (2013). The Contribution of the FIFA World Cup and the Olympic Games to Green Economy. Sustainability, 5(8), 3581-3600.

Ramdas, B., Gaalen, R.V. and Bolton, J. (2015). The announcement impact of hosting the FIFA World Cup on host country stock markets. Procedia Economics and Finance, 30, 226 $-238$.

Rodolfo Q. Aquino, R.Q. (2006). Efficiency of the Philippine stock market. Applied Economics Letters, 13(7), 463-470.

Sanchez-Granero, M., Balladares, K., Ramos-Requena, J., Trinidad-Segovia, J. (2020). Testing the efficient market hypothesis in Latin American stock markets. Physica A: Statistical Mechanics and its Applications, 540, 123082

Sathyanarayana, D., \& Gargesha, P. (2017). The Impact of Policy Announcement on Stock Market Volatility: Evidence from Currency Demonetisation in India. IOSR Journal of Business and Management, 19(01), 47-63.

Sehrawat, M. and Giri, A.K. (2017). A Sectoral Analysis of the Role of Stock Market Development on Economic Growth: Empirical Evidence from Indian Economy. Global Business Review, 18(4), 1-13.

Shaik, M. \& Maheswaran, S. (2017). Market Efficiency of ASEAN Stock Markets, Asian Economic and Financial Review, 7(2), 109-122.

Shiller, R.J. (2003). Efficient Markets Theory to Behavioral Finance. The Journal of Economic Perspectives, 17(1), 83-104.

Tien, C., Lo, H., \& Lin, H. (2011). The Economic Benefits of Mega Events: A Myth or a Reality? A Longitudinal Study on the Olympic Games. Journal of Sport Management, 25(1), 11-23.

Tokic, S., Bolfek, B. and Pesa, A. (2018). Testing efficient market hypothesis in developing Eastern European countries. Investment Management and Financial Innovations, 15(2), 281-291.

Veraros, N., Kasimati, E., \& Dawson, P. (2004). The 2004 Olympic Games Announcement and its Effect on the Athens and Milan Stock Exchanges, Applied Economics Letters, $11,749-753$.

Wibowo, W. (2014). Penerapan Model Indeks Tunggal untuk Menetapkan Komposisi Portfolio Optimal (Studi pada Saham-Saham LQ45 yang Listing di Bursa Efek Indonesia (BEI) Tahun 2010-2012). Jurnal Administrasi Bisnis, 9(1).

Yang, A.S. and Pangastuti, A. (2016). Stock market efficiency and liquidity: The Indonesia Stock Exchange merger. Research in International Business and Finance, 36, 28-40. 


\section{Author's Biography:}

D. Agus Harjito is an Associate Professor of Finance at the Department of Management in Universitas Islam Indonesia. He is a Fellow of Indonesian Management Forum. He obtained his DBA from National University of Malaysia in 2007. His research areas include corporate finance, behavioral finance, capital market and Islamic finance.

Md. Mahmudul Alam is an associate professor of finance at Universiti Utara Malaysia and an associate fellow at University Technology MARA. He is a certified financial planner as well as a certified expert in climate adaptation finance, and he was a research fellow under the Adaptation Finance Fellowship Programme (AFFP) of Frankfurt School and the Thailand Development Research Institute..

Rani Ayu Kusuma Dewi is an alumna of the Department of Management in the Universitas Islam Indonesia. She was volunteered in AIESEC Kid Speak Project Poland 2017 and awarded the best speaker. Currently she is a businesswoman and the founder of Surya Indah Kreasi Utama, an interior design company. 